ISSN 2089-8703 (Print) Vol. 6, No. 1 (2017)

ISSN 2442-5419 (Online)

\title{
PENGEMBANGAN BAHAN AJAR KALKULUS INTEGRAL BERBASIS ANIMASI
}

\author{
Ali Shodikin \\ Program Studi Pendidikan Matematika Universitas Islam Darul Ulum \\ Email: alishodikin@unisda.ac.id
}

\begin{abstract}
Learning integral calculus should be done with interesting and fun process, because this course is basic materials and a prerequisite for other subjects as well as the provision of teaching materials for high school students. However, based on the documentation that have done in one of the private universities in Lamongan in the last two years shows that the average score of student results in mathematics education and mathematics subjects integral calculus has only reached $42 \%$. This suggests that the results of student learning especially integral calculus courses still low. One effort that can be done is to develop teaching materials based animation. Media animation that comes with the animations, audio, and video in teaching and learning can grow the interest of learners. Based on these descriptions, this study aims to develop teaching materials integral calculus-based animation. This study uses a study design development consists of four stages, namely: (1) definition, (2) design, (3) development, and (4) dissemination. The end product of this research is animation-based teaching media for the course of integral calculus.
\end{abstract}

Keywords: animation, development, instructional materials, integral calculus

\section{PENDAHULUAN}

Kalkulus merupakan salah satu mata kuliah yang menjadi momok permasalahan bagi mahasiswa. Padahal mata kuliah ini berisi materi-materi dasar sebagai prasyarat mata kuliah lain, seperti sistem persamaan garis, fungsi dan limit, turunan (diferensial), serta integral. Secara khusus materi integral ditempuh dalam mata kuliah kalkulus integral.Bagi mahasiswa program studi pendidikan matematika, sebagai calon guru, selain sebagai materi dasar, mata kuliah ini juga digunakan sebagai materi ajar untuk siswa SMA nantinya.Selain menjadi mata kuliah wajib bagi program studi pendidikan matematika, mata kuliah ini juga wajib untuk mahasiswa program studi matematika dan beberapa program studi bidang teknik, seperti teknik mesin, teknik elektro dan teknik sipil.
Berdasarkan hasil dokumentasi yang dilakukan Shodikin (2016) di salah satu perguruan tinggi swasta di Kabupaten Lamongan dalam dua tahun terakhir menunjukkan bahwa rata-rata skor hasil belajar mahasiswa pendidikan matematika pada mata kuliah kalkulus integral baru mencapai $42 \%$.Hal ini menunjukkan bahwa hasil belajar mahasiswa terutama mata kuliah kalkulus integral masih rendah.Hasil dokumentasi nilai ujian tengah semester dan ujian akhir semester mahasiswa yang dilakukan oleh peneliti (Shodikin, 2016) di program studi matematika juga menunjukkan hasil belajar yang masih rendah, yakni hanya mencapai $48 \%$. Hasil studi yang dilakukan oleh Ramdani (2012) juga menyatakan hasil yang sama dan menambahkan alasan rendahnya hasil belajar disebabkan salah satunya karena faktor bahan ajar 
yang digunakan.

Bahan ajar merupakan salah satu faktor penting dalam meningkatan kualitas pembelajaran dan kemampuan yang dimiliki peserta didik. Tidak hanya meningkatkan kemampuan yang bersifat umum dalam bentuk hasil belajar (Clement, dkk, 2014) dan kognitif peserta didik (Nwike \& Catherine 2013), tetapi juga berdasarkan tingkatan kemampuan seperti membaca dan memahami (Eskey \& Grabe, 1986); representasi (Mahardika, 2011) dan berpikir kritis(Zakiyah, 2012).

Telah dikenal beberapa pendekatan pengembangan bahan ajar yang dilakukan diantaranya melalui penelitian desain (Mulyana, 2012), metakognitif (Istianah, dkk., 2012), penataan informasi (Sungkono, dkk., 2003) dan penelitian pengembangan (Borg and Gall, 1983). Pendekatan ini masing-masing mempunyai keunggulan dan kelemahan, tetapi yang terpenting adalah kesesuaian dengan karakteristik peserta didik itu sendiri. Jika hal ini tidak diperhatikan, bahan ajar dapat menghambat proses pembelajaran itu sendiri (Uzuegbu,dkk., 2013). Oleh karena itu diperlukan suatu analisis kebutuhan untuk mengidentifikasi masalah guna menentukan tindakan yang tepat.Hal ini juga sesuai dengan pernyataan Morrison (2001) bahwa analisis kebutuhan merupakan alat untuk mengidentifikasi masalah guna menentukan tindakan yang tepat. Pernyataan ini juga didukung oleh Brown (1995) dimana analisis kebutuhan merupakan cara untuk mengumpulkan informasi yang mengidentifikasi faktor-faktor pendukung dan penghambat (kesenjangan) proses pembelajaran yang dimiliki pembelajar untuk mencapai tujuan pengembangan pembelajaran yang mengarah pada peningkatan mutu pendidikan. Oleh karena itu, perlu suatu pengembangan yang didasarkan pada temuan tujuan akhir dan temuan di lapangan.Hal ini dilakukan untuk mengurangi kesenjangan kebutuhan yang ada di lapangan.

Disisi lain, pengembangan pembelajaran sudah diarahkan pada pemanfaatan teknologi, sehingga dapat menjangkau pembelajaran jarak jauh. Sayangnya belum banyak sumber belajar yang menfasilitasi pembelajaran jarak jauh ini, diantaranya pada bahan ajarnya.Bahan ajar yang ada sekarang masih jarang yang mengarahkan pada pemanfataan teknologi komputasi yang dapat dipraktekkan secara langsung.Kebanyakan bahan ajar berupa modul bahan bacaan yang berisi materi dan soal latihan dalam bentuk buku teks.Padahal inovasi bahan ajar berbasis animasi terbukti efektif dalam meningkatkan hasil belajar peserta didik (Pujadi dan Harisno, 2012). Dengan memanfaatkan software Swishmax untuk program animasi dan software Geogebra, Matematica serta Sketpath akan menghasilkan bahan ajar berbasis animasi yang dapat mendukung pembelajaran pada mata kuliah Kalkulus Integral. Berdasarkan latar belakang masalah di atas, sangat perlu dilakukan pengembangan bahan ajar kalkulus integral berbasis animasi ini.

\section{METODE PENELITIAN}

Model yang digunakan dalam penelitian pengembangan ini adalah dengan memodifikasi model 4-D (Four$D$ model) dari Thiagarajan, dkk (1974: 5-9) yang terdiri dari empat tahap, yaitu: (1) pendefinisian (define), (2) perancangan (design), (3) pengembangan (develop), dan (4) penyebaran (desseminate). Pengembangan bahan ajar model 4-D 
dalam penelitian ini disajikan dalam Gambar 1 berikut:

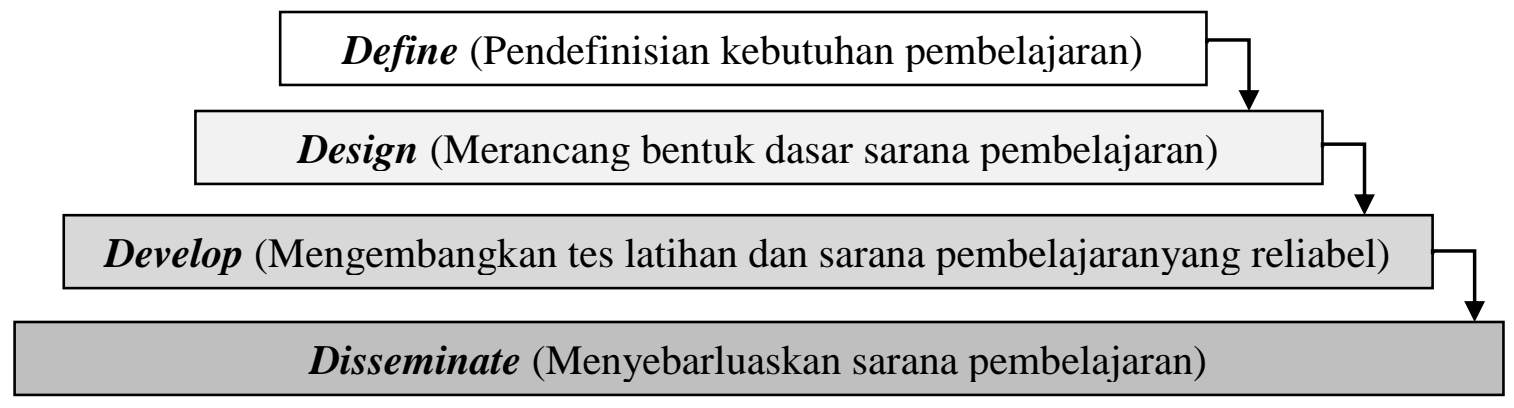

Gambar 1. Four-D Model

\section{HASIL PENELITIAN DAN PEMBAHASAN}

\section{Karakteristik Kalkulus Integral}

Mata kuliah Kalkulus Integral merupakan mata kuliah yang masuk dalam kelompok mata kuliah wajib pada program studi matematika, pendidikan matematika dan beberapa program studi teknik, seperti teknik mesin, teknik elektro dan teknik sipil di tingkat perguruan tinggi program sarjana (S1).Biasanya mata kuliah ini diprogramkan pada semester 2 dengan bobot tiga hingga empat satuan kredit semester (SKS). Secara lengkap mata kuliah ini masuk ke dalam mata kuliah kalkulus yang yang berisikan Kalkulus Diferensial, Kalkulus Integral, Kalkulus Peubah Banyak, dan Persamaan Diferensial (Tim Akademik Unisda, 2015).

Secara umum materi yang dipelajari pada perkuliahan Kalkulus Integral meliputi: integral tak tentu (anti turunan), teknik-teknik pengintegralan, integral tentu, dan aplikasi integral. Selama ini bahan ajar yang banyak digunakan untuk mata kuliah ini masih dalam bentuk modul dan diktat.

\section{Karakteristik Bahan Ajar Berbasis Animasi}

Animasi merupakan suatu teknik menampilkan obyek (gambar) secara berurutan sedemikian rupa sehingga penonton merasakan adanya ilusi gerakan (motion) pada obyek yang ditampilkan.Secara umum ilusi gerakan merupakan perubahan yang dideteksi secara visual oleh mata penonton sehingga tidak harus perubahan yang terjadi merupakan perubahan posisi sebagai makna dari istilah 'gerakan'.Perubahan seperti perubahan warna pun dapat dikatakan sebuah animasi.Gambar atau objek yang dimaksud dalam definisi di atas bisa berupa gambar manusia, hewan, maupun tulisan. Berdasarkan pengertian tersebut bahan ajar berbasis animasi dalam penelitian ini adalah bahan ajar yang dilengkapi dengan efek perubahan obyek dalam bentuk gambar, garis maupun tulisan secara berurutan sedemikian rupa sehingga peserta didik dapat merasakan adanya ilusi gerakan (motion) pada obyek yang ditampilkan. Dalam bahan ajar kalkulus integral ini juga akan dilengkapi dengan sajian dalam bentuk audio dan video simulasi.

Secara umum bagian yang terdapat dalam bahan ajar kalkulus integral berbasis animasi ini adalah halaman pembuka, halaman menu utama, petunjuk penggunan, materi, evaluasi, daftar pustaka dan profil. Produk akhir yang dihasilkan memiliki 
karakteristik yang berbeda dari bahan ajar yang lain, diantaranya: desain penyajian menekankan pada animasi grafis, terdapat beberapa bagian materi yang menggunakan cuplikan alur cerita dan video simulasi dalam penyampaiannya, serta dilengkapi contoh dan latihan soal. Pada bagian latihan soal, terdapat penilaian yang mampu menilai hasil kuis yang telah dijawab oleh siswa dan memberikan penjelasan alternatif jawaban. Untuk menguatkan pemecahan masalah secara terintegrasi, akan diberikan pada menu evaluasi yang berisi latihan soal yang merupakan gabungan beberapa indikator pembelajaran. Bahan ajar ini juga dilengkapi buku panduan penggunaan bahan ajar. Buku panduan penggunaan bahan ajar disajikan dalam bentuk cetak dan bentuk penjelasan singkat penggunan tombol pada menu petunjuk.

Dalam pengembangan bahan ajar kalkulus integral berbasis animasi ini akan digunakan beberapa software, diantaranya software Swishmax untuk program animasi dan software Geogebra, Matematica, Corel Draw untuk program pengembangan materi pembelajaran.

\section{Karakteristik SoftwareGeogebra, Swismax, dan Corel Draw}

Pemanfaatan komputer dalam pembelajaran matematika semakin relevan mengingat karakteristik yang dimiliki matematika.Tidak sebagaimana pada kajian ilmu lainnya, objek kajian matematika menurut Soedjadi (1999), adalah benda-benda pikiran yang bersifat abstrak.Hal inilah yang sering menjadi penyebab kesulitan peserta didik dalam mempelajari matematika.Di satu sisi objek kajian matematika bersifat abstrak, sementara di sisi lain, peserta didik belum mampu berpikir secara abstrak.Media pembelajaran mempunyai peran yang penting guna menjembatani kesenjangan itu.Dalam hal ini, komputer dapat berfungsi sebagai media pembelajaran yang dapat memberikan pengalaman visual kepada siswa dalam berinteraksi dengan objekobjek matematika (Mahmudi, 2010).Hal ini dapat mendorong motivasi belajar siswa karena dapat memperjelas dan mempermudah pemahaman terhadap objek-objek matematika yang bersifat abstrak.

Salah satu software yang dapat digunakan sebagai media pembelajaran matematika adalah program GeoGebra. Geogebra dikembangkan oleh Markus Hohenwarter pada tahun 2001. Menurut Hohenwarter (2008), GeoGebra adalah program komputer (software) untuk membelajarkan matematika khususnya geometri dan aljabar. Sejumlah penelitian menunjukkan bahwa GeoGebra dapat mendorong proses penemuan dan eksperimentasi peserta didik di kelas (Hohenwarter \& Fuchs 2004). Fitur-fitur visualisasi software ini dapat secara efektif membantu siswa dalam mengajukanberbagai konjektur matematis.Sebagaimana ditunjukkan oleh Shodikin (2015) bahwa software ini dapat dimanfaatkan dalam pemecahan beberapa masalah matematika kalkulus integral, seperti integral Riemann, penentuan luas daerah bidang datar, dan volume benda putar.Pemanfaatan software Geogebraditunjukkan sebagaimana Gambar 2 untuk membuat grafik dan volume benda putar: 

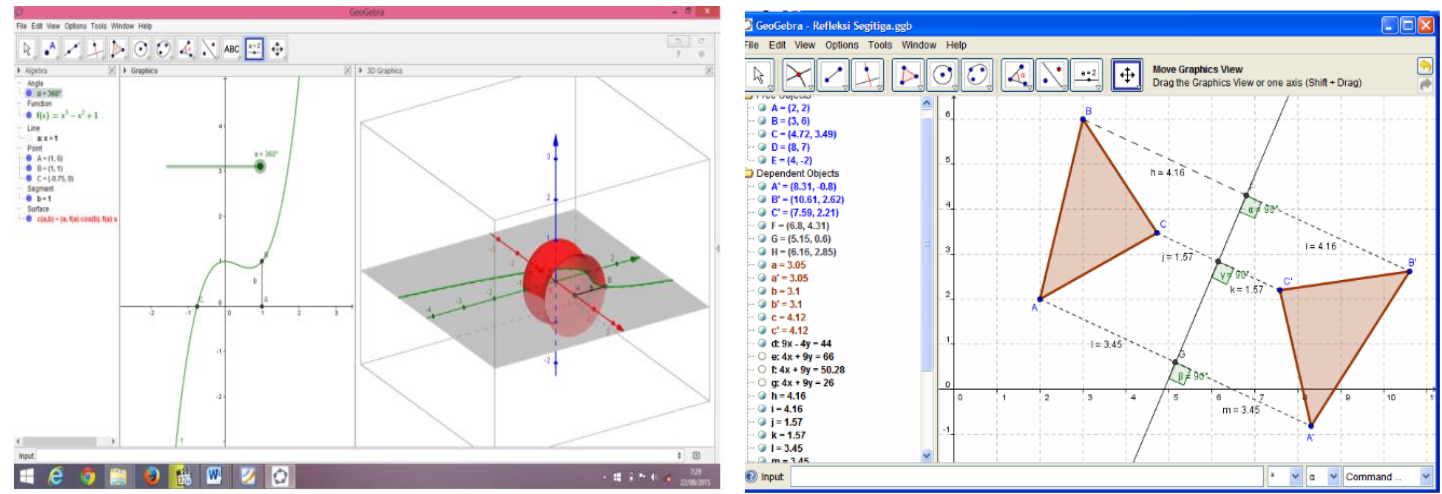

Gambar 2. Beberapa Gambaran Pemanfaatan Software Geogebra

Selanjutnya software Swishmax dikhususkan untuk menyajikan bahan ajar dalam bentuk program animasi. Swishmax merupakan program pembuat animasi untuk menghasilkan animasi Flash tanpa menggunakan Adobe Flash $^{\mathrm{TM}}$. Swishmax sangat mudah dipelajari dan dapat membuat animasi dengan teks, gambar, grafik dan suara dalam waktu singkat. Swishmax memiliki 230 efek siap pakai seperti Explode, Vortex, Snakes dan lain-lain. Swishmax memiliki tools untuk menggambar garis, rectangels, elips, kurva acak, motion path, sprites, tombol dan form masukan dengan cara yang lebih mudah. Penggunaan software ini akan lebih memudahkan dalam pengembangan bahan ajar kalkulus integral berbasis animasi. Beberapa penelitian yang telah dilakukan diantaranya oleh Hasrul (2011), Syafrudin (2013), Prihantana, dkk (2014) menunjukkan bahwa bahan ajar berbasis animasi efektif untuk pembelajaran teknik maupun teknologi pembelajaran.

Software selanjutnya yang digunakan dalam mendukung pengembangan bahan ajar berbasis animasi ini adalah software Corel Draw dengan spesifikasi X4. Software ini yang digunakan dalam mendukung desain grafis dan pembentukan obyek.
Beberapa software lain yang akan digunakan antara lain Sketchpath untuk menggambar grafik serta software Camtasia untuk mode perekaman desktop yang dilakukan untuk mendapatkan materi pembelajaran yang dilakukan oleh seorang tutor dari kegiatan awal sampai akhir. Extention akhir dari hasil capture berupa animasi yang extensinya disesuaikan.

\section{Penelitian yang Relevan dan Keterbaruan Penelitian}

Beberapa penelitian yang relevan yang mendukung penelitian pengembangan ini adalah sebagai berikut:

Mainal \& Key (2010) menunjukkan bahwa penggunaan software Geogebra dalam pembelajaran memberikan kesan, antusias dan penerimaan yang baik bagi guru dalam workshop yang diadakan untuk guruguru di Nepal. Penelitian Fitriyani (2012) menunjukkan melalui penelitian tindakan kelas selama 2 siklus, perubahan yang dilakukan adalah dengan memanfaatkan software Geogebra melalui strategi IDEAL diperoleh data tentang keaktifan siswa yang mengalami peningkatan dari $70 \%$ pada siklus 1 menjadi $90 \%$ pada siklus 2. Hasil belajar siswa juga mengalami peningkatan dari 79,11 dengan 
ketercapaian klasikal 60,71\% menjadi 84,11 dengan ketercapaian klasikal $85,7 \%$, maka dapat disimpulkan bahwa pemanfaatan software Geogebra melalui strategi IDEAL pada materi sudut pusat dan sudut keliling lingkaran dapat meningkatkan keaktifan dan hasil belajar siswa.Penelitian Trans, dkk (2014) yang dilakukan pada 282 siswa menunjukkan79\% peserta didik seringmenggunakan kembali GeoGebra dalam mengecek pemahaman mereka secara mandiri (tanpa perintah guru), 16 $\%$ kadang-kadang dan hanya $5 \%$ yang tidak melakukannya lagi di rumah. Hal ini menunjukkan bahwa software ini memberikan daya tarik tersendiri bagi peserta didik.

Sedangkan dalam efektivitas bahan ajar berbasis animasi atau multimedia terbukti efektif dalam meningkatkan kualitas pembelajaran. Hal ini ditunjukkan dari penelitian Hasrul (2011) yang menunjukkan bahwa berdasarkan hasil analisis deskriptif, pandangan mahasiswa JPTE FT UNM terhadap Animasi Adobe Flash CS3 dalam pembelajaran Instalasi Listrik 2 berada diatas rata-rata dengan kategori baik atau sebesar $75 \%$. Syafrudin (2013) menyimpulkan bahwa film animasi merupakan alat bantu pembelajaran yang digunakan oleh guru maupun orang tua dalam memberikan variasi pengajaran sehingga dapat memotivasi anak untuk belajar karena belajar menjadi menyenangkan karena adanya unsur hiburan. Prihantana, dkk (2014) menunjukkan bahwa tanggapan ahli isi, ahli media dan guru mata pelajaran serta siswa berada pada kualifikasi sangat baik. Selanjutnya tingkat keefektifan bahan ajar interaktif berbasis pendidikan karakter meningkatkan hasil belajar ditunjukkan dengan nilai hasil hitung gain score sebesar 0,76 yang berada pada kriteria tinggi.

\begin{abstract}
Keterbaruan
penelitian pengembangan ini adalah penggabungan antara pemanfaatan software Geogebra yang disajikan dalam bahan ajar berbasis animasi.
\end{abstract}

\section{Analisa Kebutuhan Perangkat Keras dan Perangkat Lunak}

Untuk membuat suatu produk bahan ajar kalkulus integral berbasis animasi yang baik diperlukan perangkat keras yang memadai untuk sebuah proses produksi. Sebagaimana tersirat dalam kajian sebelumnya, perangkat keras yang harus dipenuhi dalam pengembangan bahan ajar kalkulus integral berbasis animasi ini, antara lain: Prosessor Intel P4 2.80 Ghz, Memory DDR $512 \mathrm{Mb}$, CD ROOM Rewriteable, VGA $64 \mathrm{Mb}$ on board atau exsternal, SoundCard on board atau exsternal, Monitor 17', Keyboard, Headseat, Microfone, dan Handycam (opsional). Sedangkan perangkat lunak (software) utama yang digunakan yaitu:Geogebra 3D, Swismax 3D, Corel Draw X4, dan Camtasia untuk Capture desktop.

\section{Rancangan Pengembangan Produk}

Dalam rancangan pengembangan produk bahan ajar kalkulus integral berbasis animasi ini penjelasan lebih detail disajikan sebagai berikut.

\section{Perancangan Navigasi}

Sebelum diadakan pembuatan layout tutorial perlu dipikirkan dahulu bagaimana sebuah alur tutorial yang menerangkan tentang jalannya sebuah proses, agar dalam perancangannya nanti menjadi mudah dan terstruktur. Berikut gambar dari sebuah bagan alur tutorial. Sebelum memasuki teknis perancangan terlebih dahulu perlu dipikirkan bagaimana proses manajemen filenya. Dalam perancangan tutorial ini menerapkan sistem layering 
file, artinya proyek terdiri dari beberapa file yang proses penampilanya bertingkat atau level, dalam hal proses loading file disesuaikan dengan kebutuhan. Jadi file yang tidak dibutuhkan tidak ditampilkan dengan maksud tujuan untuk mempercepat loading file. Berikut contoh gambar diagram manajemen file.

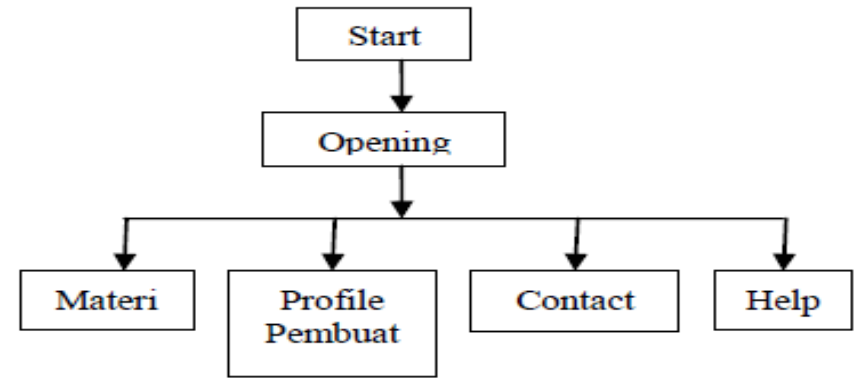

Gambar 3. Manajemen File

\section{Perancangan Tampilan}

Berdasarkan kegiatan user, bagan alur tutorial, dan manajemen file, maka selanjutnya sudah bisa dibuatkan perancangan masing-masing tampilan antara lain: perancangan opening, tampilan pertama, materi tutorial, profile, contact, help.

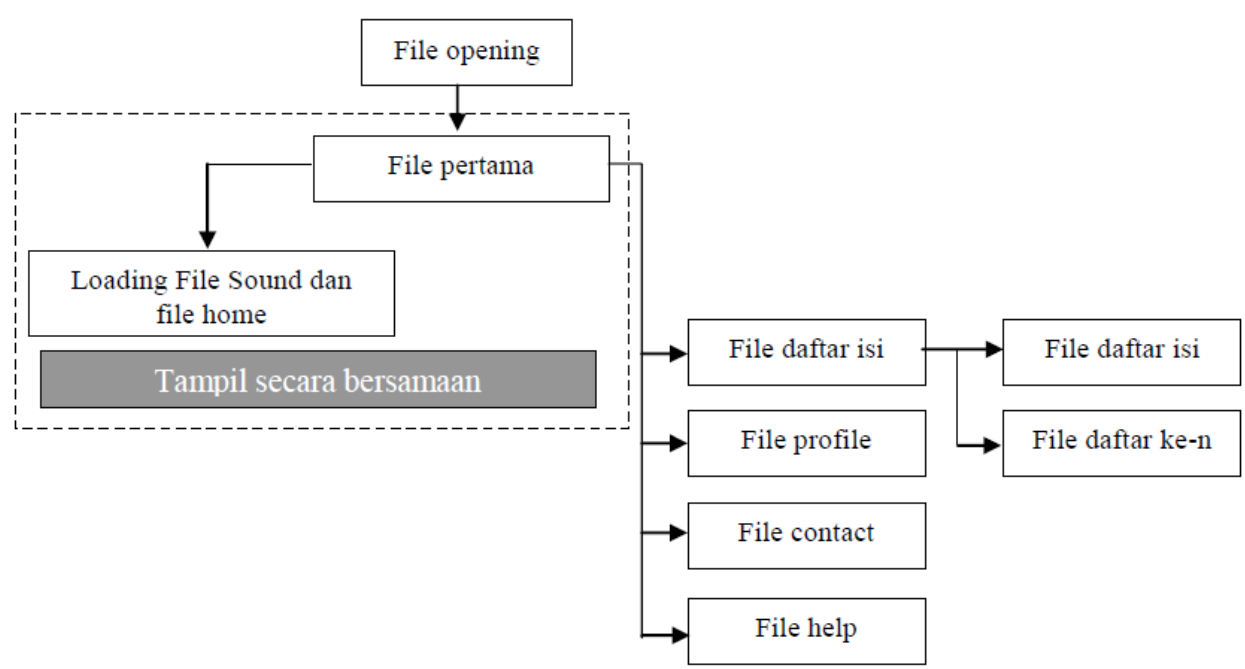

Gambar 4. Bagan Manajemen File Perancangan Tampilan

\section{Perancangan Opening}

Pada perancangan opening dibuat sederhana mungkin, supaya jumlah file kecil dengan alasannya supaya loading pertama menjadi cepat. Sedangkan besarnya tampilan, menggunakan standar resolusi monitor yang terkecil 800 X 600 pixel. 
ISSN 2089-8703 (Print) Vol. 6, No. 1 (2017)

ISSN 2442-5419 (Online)

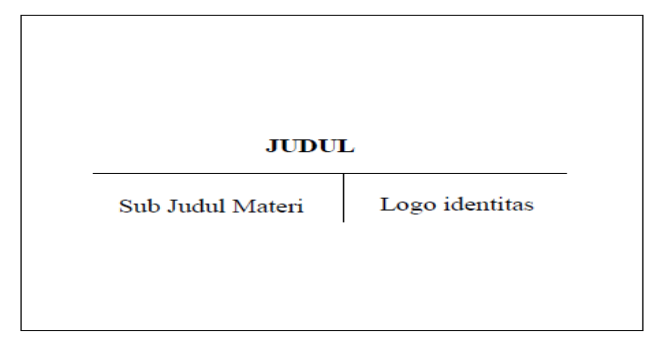

Gambar 5. Desain Tampilan Pembuka

\section{Perancangan Tampilan Awal}

Pada perancangan tampilan awal ini disediakan fasiltas-fasilitas yang sekiranya dibutuhkan user, baik yang tampil secara langsung atau melalui proses klik button

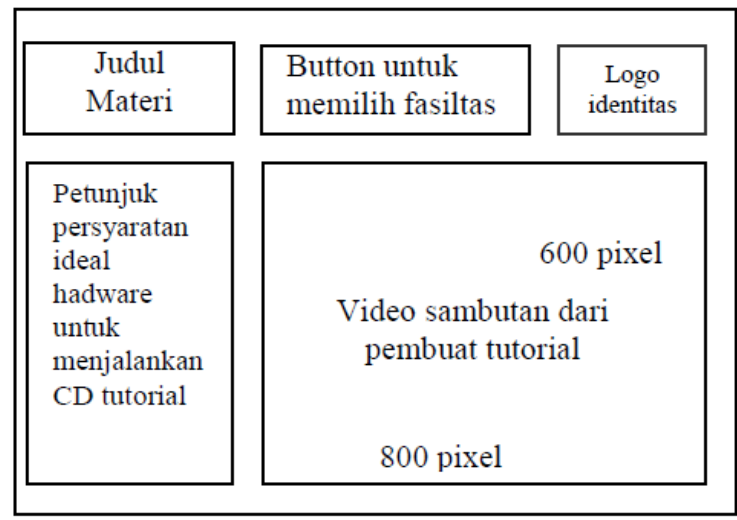

Gambar 6. Desain Tampilan Awal

Perancangan Tampilan Daftar Isi

Pada tampilan daftar isi sebenarnya terdiri dari dua tampilan, daftar isi dan materi tutorial.
Sebenarnya tampilan materi tutorial ditampilkan sesuai kebutuhan secara bergantian.

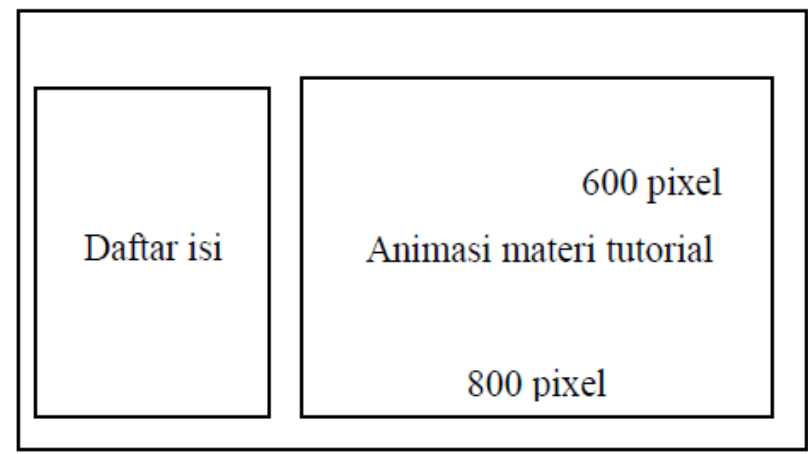

Gambar 7. Desain Tampilan Daftar Isi

\section{KESIMPULAN DAN SARAN}

Berdasarkan pembahasan di atas dapat disimpulkan dua hal yaitu(1) menjadi suatu hal yang penting untuk mengembangkan bahan ajar kalkulus integral berbasis animasi dan (2) dengan konsep rancangan pengembangan produk yang ditawarkan akan menghasilkan produk akhir bahan ajar berbasis animasi yang berkualitas. 
Untuk mewujudkan hal tersebut, disarankan kepada peneliti dan pengembang media pembelajaran untuk bersinergi mengembangkan bahan ajar kalkulus integral berbasis animasi sehingga dihasilkan produk yang bermanfaat bagi khalayak umum khususnya mahasiswa dan pengajar kalkulus intergal.

\section{DAFTAR PUSTAKA}

Borg and Gall. 1983. Educational Research, An Introduction. New York and London: Longman Inc.

Brown, J. D. 1995.The Elements of Language Curriculum. Boston: Mass Heinle \& Heinle Publishers.

Clement, Iji O., Ogbole Patience O.,\&Uka Nanna K. 2014.Effect of Improvised Instructional Materials on Students' Achievement in Geometry at the Upper Basic Education Level in Makurdi Metropolis, Benue State, Nigeria.American Journal of Educational Research.Vol. 2, No. 7, Hal 538-542.

Eskey, D.E., \& Grabe, W. 1986.Teaching Second Language: Reading for Academic Purposes.Addison: Wesley Publishing Co.

Fitriyani, W. 2012.Pemanfaatan Software Geogebra Melalui Strategi Ideal pada Materi Sudut Pusat dan Sudut Keliling Lingkaran Untuk Meningkatkan Keaktifan dan Hasil Belajar Siswa Kelas VIII F SMP Negeri 3 Pati Tahun Pelajaran 2011/2012.Prosiding Seminar Nasional Matematika dan Pendidikan

Matematika.Yogyakarta: Jurusan Pendidikan Matematika Universitas Negeri Yogyakarta. ISBN: 978-979-16353-8-7.
Hasrul. 2011. Desain Media Pembelajaran Animasi Berbasis Adobe Flash Cs3 pada Mata Kuliah Instalasi Listrik 2. Jurnal MEDTEK. Vol. 3, No. 2, Hal 110.

Hohenwarter, M., et al. 2008.Teaching and Learning Calculus with Free DynamicMatgematics Software GeoGebra.http://www.publicati ons.uni.lu/record/2718/files/ICM E11-TSG16.pdf.diakses tanggal 15 April 2016.

Hohenwarter, M. \& Fuchs, K. 2004.Combination of Dynamic Geometry, Algebra, and Calculus in the Software System Geogebra.

http://www.geogebra.org/publica tions/pecs_2004.pdf. diakses tanggal 15 April 2016.

Istianah, Widodo, J., \& Eko Prasetya, E. 2012. Pengembangan Bahan Ajar dengan Pendekatan Metakognisi pada Materi Permintaan dan Penawaran Kelas X SMA Negeri 3 Demak. Journal of Educational Social Studies (JESS).Vol. 1, No. 1, Hal 1-12.

Mahardika, I. M.2011. Pengembangan Bahan Ajar Mekanika untuk Meningkatkan Kemampuan Representasi Verbal, Matematis, Gambar, dan Grafik Mahasiswa Calon Guru Fisika. Disertasi. Universitas Pendidikan Indonesia.

Mahmudi, A. 2010.Membelajarkan Geometri dengan Program GeoGebra.Makalah dipresentasikan dalam Seminar Nasional Matematika dan Pendidikan Matematika pada tanggal 27 November 2010 di Jurusan Pendidikan Matematika FMIPA UNY. 
Mainal, B.R. \& Key, M. B. 2010.Using Dynamic Geometry Software GeoGebra in Developing Countries: A Case Study of Impressions of Mathematics Teachers in Nepal.International Journal for Mathematics Teaching and Learning. Vol.11, No.1, Hal 1-16.

Morrison, G. R, Steven M, Ross,\&Jerrold E Kemp. 2001. Designing Effective Instruction. Edisi 3. USA: John Wiley and Sons.

Mulyana, T. 2012. Pengembangan Bahan Ajar Melalui Penelitian Desain.Jurnal Ilmiah Program Studi Matematika STKIP Siliwangi Bandung.Vol.1, No. 2, Hal 32-39.

Nwike, Matthew C., \& Catherine, O., 2013. Effects of Use of Instructional Materials on Students Cognitive Achievement in Agricultural Science.Journal of Educational and Social Research.Vol.3, No. 5, Hal 4351.

Prihantana, Santyasa, \& Warpala. 2014. Pengembangan Bahan Ajar Interaktif Berbasis Pendidikan Karakter pada Mata Pelajaran Animasi Stop Motion Untuk Siswa SMK. e-Journal Program Pascasarjana Universitas Pendidikan Ganesha Program Studi Teknologi Pembelajaran. Vol. 4, No. 1, 1-12.

Pujadi, T.dan Harisno.2012. Pengembangan Model Perangkat Ajar BerbasisAnimasi Studi Kasus: Mata Ajar Biologi pada SMPYaspia dan SMK Bina Manajemen Cakung Jakarta Timur. JSM STMIK Mikroskil.Vol.13, No. 2, Hal149158.

Ramdani, Y. 2012. Pengembangan
Instrumen dan Bahan Ajar Untuk Meningkatkan Kemampuan Komunikasi, Penalaran, dan Koneksi Matematis Dalam Konsep Integral.Jurnal Penelitian Pendidikan.Vol.13, No. 1, Hal 39-49.

Shodikin, A. 2015.Penggunaan Software Geogebra 3D dalam Beberapa Pemecahan Masalah Matematika Kalkulus Integral.Prosiding Seminar NasionalMatematika dan Pembelajarannya.5 September 2015, Malang, Indonesia. Hal.119-132.

Shodikin, A. 2016. Dokumentasi Hasil Belajar Kalkulus Integral Jurusan Matematika 2016. Lamongan: Perpustakaan Jurusan Matematika Unisda.

Soedjadi, R. 1999. Kiat Pendidikan Matematika di Indonesia (Konstatasi Keadaan Masa Kini Menuju Harapan Masa Depan). Jakarta: Dirjen Dikti.

Sungkono, dkk. 2003. Pengembangan Bahan Ajar. Yogyakarta: FIP Universitas Negeri Yogyakarta.

Syafrudin, C. \& Wahyu Pujiyono. 2013. Pembuatan Film Animasi Pendek "Dahsyatnya Sedekah" Berbasis Multimedia Menggunakan Teknik 2D Hybrid Animation dengan Pemanfaatan Graphic. Jurnal Sarjana Teknik Informatika. Vol. 1, No. 1, Hal 387-398.

Thiagarajan, S., D. S. Semmel, and M. I. Semmel. 1974. Instructional Development for Training Teachers of Exceptional Children, A Source Book. Blomington: Indiana University.

Tim Akademik Unisda. 2015.Pedoman Studi Universitas Islam Darul Ulum Lamongan.Lamongan: 
ISSN 2089-8703 (Print) Vol. 6, No. 1 (2017)

ISSN 2442-5419 (Online)

Universitas Islam Darul Ulum.

Tran, T., Nguyen, N., Bui, M., \& Phan,

A. 2014.Discovery Learning

with the Help of the GeoGebra

Dynamic Geometry

Software.International Journal

of Learning, Teaching and Educational Research.Vol.7, No.

1, Hal 44-57.

Uzuegbu C.P., Mbadiwe, H. C., \& Anulobi, J.C. 2013. Availability and Utilisation of Instructional Materials in Teaching and Learning of Library Education in Tertiary Institutions in Abia State.Wudpecker Journal of Educational Research, Vol. 2, No. 8, Hal 111 - 120.

Zakiyah, M. 2012. Pengembangan Bahan Ajar Pendidikan Berpikir Kritis Melalui Pembelajaran Menulis Karya Ilmiah di SMA/MA Kelas XI.Jurnal Online Universitas Negeri Malang.http://jurnalonline.um.ac.id/data/artikel/artik el7FCEEE9CC1FAF56E9B661 B2F44619E45.pdf. 